удк $378.01 .01+378.013$

Ольга Очеретна

Національний університет

«Одеська морська академія»

ORCID ID 0000-0001-7077-4878

DOI 10.24139/2312-5993/2019.07/265-276

\title{
ЕКОНОМІЧНИЙ ПОТЕНЦІАЛ АКМЕОЛОГІЧНИХ ТЕХНОЛОГІЙ У ПІДВИЩЕННІ ЯКОСТІ ПРОФЕСІЙНОÏ ОСВІТИ
}

у статті актуалізовано проблему якості освіти в контексті сучасної компетентнісної парадигми, реформування освітнього простору та впливу на них економічного фактору. Звернено увагу на людиноцентричний аспект якості освіти, у межах якого враховано як суспільно-потребовий контекст, так і індивідуальнопотребовий. Акцентовано значущість економічної компетентності майбутнього фахівця, яка кореспондується за функцією з інтегральною компетентністю та може бути застосована як у межах професійної діяльності, так і в соціокультурному просторі в цілому. У цьому ракурсі розглянуто потенціал акмеологічних технологій, які є зручним, сучасним та дієвим педагогічним засобом розвитку особистості та ії професійного зростання, зокрема впливаючи і на економічну компетентність особистості.

Ключові слова: якість освіти, економічна компетентність майбутнього фахівця, акмеологічні технології, економічний потенціал акмеологічних технологій.

Постановка проблеми. На етапах активних обговорювань реформування суспільства, або його кардинальних перетворень, актуалізується проблема підвищення якості освіти майбутніх фахівців. Ця закономірність $є$ цілком зрозумілою, оскільки оновлення суспільства потребує від них інших, осучаснених компетентностей. Професійна підготовка стає епіцентром обговорювання питань підвищення якості освіти різних галузей знань. Якщо технічна галузь зв'язана з інноваціями в досягненнях IKT, машинобудівництва, промисловості, тобто тих, що напряму залежать від технологізації розвитку суспільства, то гуманітарна сфера залежить від світоглядного, ціннісного, національно-духовного контексту підготовки особистості, відповідного новим соціокультурним перетворенням суспільства.

Матеріальна та духовна частина культури розвиваються протягом усіх етапів еволюції людства паралельно. Вони взаємозв'язані: матеріальна стає чинником розвитку духовної культури, водночас духовна культура стимулює розвиток особистості та її здатність створювати нові продукти матеріального порядку. Нерідко сам науковий прошарок стає фактором поєднання матеріальної та духовної культури людства. Так, сьогодні, коли українське суспільство спрямовує свою стратегію до європейського простору, спирається й на свої здобутки, зокрема в IКТ технологіях. Це, у 
свою чергу, стимулює якісніше володіння англійською мовою, що регулюється політикою управління якістю освіти з боку МОН. Вивчаючи мову того чи іншого народу, не можна уникнути ії народно-ментальної основи, цієї історико-культурної, народно-етнічної складової, у межах якої ця мова розвивалася та еволюціонувала.

На межі XX та XXI століття спостерігалося активне обговорення в науковому дискурсі питань управління якістю освіти. Зокрема, інтерес викликав такий новий ракурс, як менеджмент освіти (Т. Алексєєнко, М. Гриньова, В. Демчук, В. Крижко, М. Мартиненко та ін.).

Сьогодні питання якості освіти знов стає актуальним у контексті відповідності вимогам часу та стратегії розвитку держави. Але фактором цієї якості нерідко стає економічний аспект професійної підготовки майбутнього фахівця, який входить у світ ринкової економіки, у систему економічних відносин і в цьому процесі має бути конкурентоспроможним.

Ця проблема актуалізує не лише розробку якісно оформлених, системно розроблених освітніх програм та низку компетентностей, на формування яких вони спрямовані. Актуальним стає розвиток самої особистості, її здатність до саморозвитку, самозміни, самоефективності в складних мінливих умовах соціокультурного середовища, яке детерміноване динамікою економічних трансформацій. Отже майбутній фахівець у своїй професійній підготовці має мати відповідний економікокультурний особистісний конструкт. 3 педагогічного погляду, його сутність виявляється через відповідні компетентності: інтегральну, економічну та ін.

Разом із тим, домінування гуманітарної парадигми освіти вплинуло й на питання підвищення ії якості в напрямі індивідуального, людиноцентричного виміру. Йдеться про якість підготовки кожної окремої особистості, яка в процесі професійного становлення здобула вищого рівня свого розвитку, кваліфікованості, що відповідає віку, фаху та має перспективи подальшого вдосконалення.

У контексті зазначеного, акмеологічні технології, що розглядаються саме як інноваційні та людиноцентричні, гуманітарні та творчі, відповідають вимогам часу. Їх педагогічний потенціал $€$ ефективним і в різних аспектах. У контексті актуалізації економічного фактору впливу на якість професійної освіти виникає потреба в уточненні саме економічного потенціалу акмеологічних технологій як педагогічного ресурсу на розвиток професійних якостей особистості.

Аналіз актуальних досліджень. Перши згадки про управління освітою знаходимо в працях Дж. Дьюї, П. Монро, В. Рейна. Актуальні питання підвищення якості освіти в компетентнісній парадигмі розглянуто в дослідженнях та доробках М. Євтуха, Е. Карпової, З. Курлянд, О. Любчук, О. Овчарук, Т. Хлєбніковою, А. Хуторського та ін. А. Губа застосовує поняття «менеджменту освіти» розводячи його сутність із поняттям «управління». 
Актуальними $€$ питання кваліметрії якості освіти, що позначає результати функції контролю, моніторингу (В. Беспалько, О. Субетто та ін.). Сучасні вчені Л. Бєлова, В. Бульба, О. Поступна вказують, що якість освіти системне утворення. До нього входять: «якість розроблення й функціонування державних механізмів регулювання освітніх процесів, якість управління освітою, якість умов забезпечення освіти (матеріальнотехнічне, інформаційне, фінансове, кадрове тощо), якість педагогічних працівників, якість освітнього процесу, якість результатів освіти (особистості) та ін. (Белова, 2018, с. 6).

Економічний аспект якості освіти, зокрема в компетентнісній парадигмі підготовки майбутніх фахівців різного профілю, представлений у доробках і дослідженнях О. Коваленко, Є. Лодатко, В. Москова, О. Падалко, Н. Пасичник, Д. Розуменко, 3. Шпунтова та ін. Актуальним стає людиноцентричний аспект економічного розвитку держави (В. Антонюк, А. Дзундза, Ю. Зайцев, Л. Кицкай, Н. Марущак, В. Москаленко, О. Соскін та ін.). У зв'язку з цим увагу привертає педагогічний потенціал акмеологічних технологій, який ґрунтовно представлений у дослідженнях О. Антонової, В. Гладкової, О. Дубасенюк, Л. Рибалко, Г. Яворської та ін.

Мета статті - обґрунтувати та визначити сутність економічного потенціалу акмеологічних технологій у контексті професійної підготовки майбутніх фахівців як чинника підвищення якості освіти у контексті їі реформування.

Для забезпечення досягнення поставленої мети застосовуються такі методи: 1) аналіз наукових джерел із проблем якості освіти, ії економічного контенту; 2) узагальнення особливостей економічної складової професійної підготовки майбутніх фахівців різного профілю; 3) теоретичне моделювання з метою визначення економічного потенціалу акмеологічних технологій.

Виклад основного матеріалу. Якщо розглядати економічну складову професійної підготовки не лише у вузькому смислі, а саме як набуття матеріального надприбутку за рахунок якісного господарювання, а як потенціал для якісного набуття професійних компетентностей, що надають переваги на ринку праці, для оптимізації здатності самостійно приймати рішення, діяти ефективно та творчо підходити до проблем виробництва, управління й набуття освіти у формальний та неформальний спосіб, то акмеологічні технології стають саме тим педагогічним ресурсом у вищій школі, які несуть у собі економічний потенціал. Розглянемо цю позицію нашого дослідження ґрунтовніше.

Як слушно вказують науковці О. Любчук та А. Хлебнікова, «...перехід у професійному навчанні до впровадження компетентнісного підходу означає переорієнтацію з процесу на результат вищої професійної освіти в діяльнісному вимірі» (Любчук, 2018). Цей вектор відповідає сучасним 
вимогам щодо самостійності майбутніх фахівців, яку вони опановують під час професійного становлення. Оцінювання якісної освіти дійсно орієнтовано в усьому світі на самостійність, автономність та відповідальність молодої особи, яка приступає до кар'єрного зростання. М. Євтух також зв'язує якість освіти з компетентнісним підходом, який робить «...надану вищу освіту прозорою, зрозумілою, зіставлюваною в межах європейських кваліфікаційних рамок для європейського простору вищої освіти та навчання впродовж життя, національних систем кваліфікацій» (Академія педагогічних наук України, с. 122).

Учені Л. Бєлова, В. Бульба та О. Поступна вказують на важливість розуміння феномену якості освіти з боку самих освітян, оскільки його складність викликає певні розбіжності в інтерпретації (Белова, 2018). Про різновекторність якості освіти пише Т. Хлебникова (Хлєбнікова, 2011). Учена зауважує, що ця категорія $\epsilon$ «..багатогранною..», оскільки «...відображає різні аспекти освітнього процесу - філософські, соціальні, педагогічні, політичні, демографічні, економічні та інші». Дослідниця розглядає якість освіти «.. як сукупність властивостей освіти, що визначають іï здатність задовольняти відповідні потреби особистості, суспільства, держави відповідно до призначення освіти». Звертаємо увагу, що йдеться не лише про потреби суспільства й держави, що переважає в інтерпретаціях якості освіти, а саме потреба особистості (Хлєбнікова, 2011).

Суголосною актуальності проблеми, що розглядається, є твердження Т. Хлєбнікової, що «якість освіти - це нагальна потреба часу. Управління даною проблемою повинно здійснюватися на основі виявлення проблем і розробки технології подолання виявлених проблем» (Хлєбнікова, 2011). Дослідниця пропонує для оцінювання якості кваліметричний метод. Не зменшуючи його переваги, все ж зазначимо, що він якісно спрацьовує для оцінювання системи якості освіти закладу в цілому, проте йому бракує точних механізмів ураховувати ці індивідуальні, особливі ознаки отримання якісної освіти з боку окремої особистості в ії розумінні професійного становлення та зростання.

Дійсно, якість освіти має встановлюватися моніторингом. Але до кожної особистості має бути застосовані певні технології моніторингу, що враховують студентоцентризм та потреби кожної особистості. Акмеологічні технології, наприклад, також мають свій вимірюваний апарат, який ґрунтується на акмеологічних критеріях та показниках. Як пишуть учені Г. Яворська, В. Гладкова, О. Горчакова, акмеологічні критерії водночас «об’єктивні та суб'єктивні», оскільки враховують «об'єктивні характеристики професіоналізму» та результати «..самооцінки, самоконтролю, образу «Я», суб'єкта розвитку» (Яворська та ін., 2012, с. 99).

Стосовно економічного аспекту професійної підготовки майбутніх фахівців, який сьогодні є вкрай затребуваним, вкажемо, що він розглядається 
як на рівні різновекторності професійної підготовки, так і на рівні розвитку ефективності праці кожної особистості, що надає їй конкурентної переваги. Отже, він відповідає людиновимірній концепції освіти.

$\epsilon$. Лодатко вказує, що ідея створення класів економічного профілювання була актуальною, але не стала «життєздатною». Разом із тим, питання «..набуття вчителями економічної компетентності лишилось у професійному тренді» (Лодатко, 2018, с. 216). Дійсно, учитель, як і представники інших професій, $є$ учасниками економічних відносин. Це впливає і на їх професійну діяльність, і на загальну професійну, зокрема й педагогічну культуру, а отже набуття економічної компетентності дедалі $\epsilon$ актуальним процесом професійної підготовки. Але на цей процес можна подивитися і з точки зору саморозвитку, самоефективності самого фахівця. Бути ефективним, кваліфікованим - означає сьогодні бути конкурентоспроможнім. Це також має економічний аспект підготовки професіонала.

Навіть якщо економічна освіта, економічне виховання не стає безпосереднім профілем діяльності, але воно $\epsilon$ обов'язковоопосередкованим для будь-якої людини, фахівця, особливо вчителя. Оскільки вчитель формує в учнів уміння якісно навчатися, що стає основою для якісного працевлаштування в майбутньому. Отже, якісна освіта в економічному контексті не лише надає глибинні знання та формує відповідні суспільству компетентності, а й формує в процесі професійної підготовки (а в школі - у процесі навчання) такі якості, як оптимізація витрат власного часу, людського ресурсу, бережливість до суспільного майна, уміння ефективно вести господарювання, навіть особистісне, намагатися ефективно працювати, ефективно та результативно вчитися. Отже, ці якості актуальні для людини взагалі, і не лише в матеріально-економічному сенсі, а й у професійному, особистісному і міжособистісно-етичному.

Якщо звернутися до виховного аспекту, суголосним є твердження Є.Лодатко, «..що вирішення завдань економічного виховання учнів загальноосвітніх шкіл на шляху розпочатого реформування української школи вимагає від учителів належної підготовки, яка не обмежується їх обізнаністю з базових економічних понять загалом, а передбачає досягнення ними певного рівня економічного виховання та економічної компетентності» (Лодатко, 2018, с. 218). Така компетентність безумовно формується в процесі професійної підготовки майбутніх учителів, зокрема й філологів, учителів англійської мови та ін.

Економічна компетентність розглядається сучасними вченими в Україні відповідно до їх фахової підготовки. Так, наприклад, О. Любчук та А. Хлебнікова розкривають таку професійну якість, як економічна компетентність як частину професійної компетентності майбутнього фахівця, зокрема студентів спеціальності «соціальна робота» (Любчук, 2018). Учені вказують, що «...сучасні вимоги до професійної компетентності соціальних 
працівників...» здійснюється в різних формах «...јнтерактивного навчання, проведення виробничої практики з урахуванням функціональної діяльності фахівця в умовах ринкової економіки». Економічна компетентність розглядається вченими як складова «..професійної компетентності для досягнення більших можливостей у самореалізації соціального працівника в умовах розвитку креативної економіки, становлення ринку кваліфікацій у країнах Європейського Союзу» (Любчук, 2018).

Розглядаючи структуру економічної компетентності, $Є$. Лодатко слушно вказує на «...необхідність ії подальшої змістової деталізації залежно від специфіки професійної діяльності фахівця. Якщо йдеться про вчителів-предметників загальноосвітньої школи, то зміст їхньої професійної діяльності буде слугувати підґрунтям для виокремлення типових здатностей, за допомогою яких може визначатися кожен зі складників економічної компетентності» (Лодатко, 2018, с. 219).

Навіть протилежна гуманітарним спеціальностям сфера, наприклад, будівельників, стає предметом визначення структури економічної компетентності. Так, наприклад, В. Москов досліджує та визначає модель економічної культури кваліфікованих робітників будівельного профілю (Кінах, 2017). Звертаємо увагу на те, що дослідник слушно обґрунтовує два поняття: «модель фахівця» і «модель підготовки фахівця» (Кінах, 2017, с. 46). Якщо перша стосується саме якостей, відповідних обраному виду професійної діяльності особистості; то другий торкається проблем саме якості освітнього процесу: «містить цілі навчання, зміст освіти, навчальні плани, програми, проекти педагогічних технологій» (Москов, 2017, с. 46). Дослідник убачає за необхідне формувати такі компоненти економічної компетентності, як мотиваційно-ціннісний, когнітивний та діяльнісний (Москов, 2017, с. 48).

Звертаємо увагу на концепцію щодо структури економічної компетентності в доробку В. Кінах. Зокрема вчена вказує на власні узагальнення аналізу літератури з проблеми структури економічної компетентності щодо того, що «існуючі компоненти економічної компетентності $€$ слушними, а саме: мотиваційно-ціннісний, когнітивний та діяльнісний» (Кінах, 2017, с. 53). Звертаємо також увагу на елементи, що складають визначенні компоненти. Мотиваційно-ціннісний містить мотиви, потреби, особистісні якості, ціннісні орієнтації; когнітивний - знання; діяльнісний - досвід і творчу діяльність (Там само). На завершення аналізу позиції дослідниці варто звернути увагу знов такі на якості, які формуються внаслідок опанування економічною компетентністю: «...ретельність та системність у роботі, посидючість, відповідальність, дисциплінованість, цілеспрямованість, оперативність (швидке реагування на різноманітні ситуації), ділова завзятість і наполегливість, ерудованість, упевненість у собі» (Кінах, 2017, с. 53).

Формуванню таких якостей допомагають певні технології, до яких дослідниця відносить і такі, що стимлюють кмитливість, активізують 
творчий ресурс, винахідливість. Йдеться про такі завдання та методичні ресурси, що відповідають акмеологічним ознакам. Зокрема, Кінах пропонує проектно-технологічний підхід, але методи, що його реалізовують, можна віднести до акмеологічних технологій. Так, наприклад, метод Webquest - «Пошуки в Мережі», який, як пояснює автор «... заснований на теорії конструктивізму, а саме розвитку своїх знань через досвід, отриманий у результаті власної діяльності (мотивація до вивчення)». Технологія безумовно ґрунтується на застосуванні мережі Інтернет. Але метод активізує пізнавальну діяльність, стимулює мотивацію до навчання, через те, що учні «...накопичують, редагують і готують для представлення за допомогою електронних засобів» отриману інформацію (Кінах, 2017, с. 53-54). Вони користуються Power Point для презентацій. Це, на нашу думку, певною мірою поєднує їх когнітивні та творчі ресурси, стимулює до винахідливості, що відповідає засадничим аспектам акмеології, водночас формує сучасні вміння працювати ефективно, креативно та винахідливо, що кореспондується з економічною стратегією розвитку сучасного професіонала.

Стосовно економічного потенціалу акмеологічних технологій вкажемо на слушну думку О. Антонової, яка акцентує на тому, що «...одним із провідних чинників економічного розвитку визнається інтелектуальне виробництво» (Антонова, 2016). Інтелектуальна власність - одна з сучасних форм власності, яка пов'язана саме з винахідливістю, когнітивною обдарованістю людини. Тому «..вивчення інтелекту, психологічних механізмів та педагогічних засобів розвитку інтелектуальної, академічної та інших видів обдарованості, ...стає одним із пріоритетних завдань наукових досліджень» (Антонова, 2016). Нам імпонує позиція акмеології, стосовно якої «...інтелектуальна творчість як невід'ємна складова людської духовності та передумова особистої свободи людини виступає тим соціальним механізмом, що протистоїть регресивним тенденціям становлення суспільства з огляду на те, що тільки робота інтелекту може забезпечити можливість появи нового знання» (Антонова, 2016).

Іншим аспектом, що актуалізує економічний потенціал акмеологічних технологій, $є$ ціннісний вектор економічного виховання учнів, еконономічної компетентності як людини, так і професіонала в цілому. Так, наприклад, О. Сомик стверджує, що «..осмислення суспільнополітичних та соціально-економічних процесів указує на те, що науковці все більше звертаються до використання поняття «цінності» та 3 використанням так званого ціннісного підходу намагаються пояснити чому все саме так, а не інакше (Сомик, 2019). Дійсно, людина спирається на сформовану в неї систему цінностей під час як матеріальних витрат, так і вибору пріоритетів у розподілі власного людського ресурсу. Такі традиції $\epsilon$ достатньо стійкими, можуть мати родинний характер, а можуть, навпаки, 
маючи негативний приклад батьків, спонукати молоду людину на уявлення цінностей іншого порядку. Отже, цінності варто не лише досліджувати, констатувати, вивчати, але й формувати. Відповідно до цінностей у вимірі економічного середовища, О. Сомик надає цьому поняттю таке уточнення: «Цінності - це елементи духовної та (або) матеріальної сфер життєдіяльності, яким надається першочергове значення та які вважаються людиною вкрай необхідними для задоволення духовних або матеріальних потреб» (Сомик, 2019). Якщо в контексті економіки минулого та й сучасності цінностями вважаються природні ресурси, то в парадигмі економічної філософії майбутнього до переважних цінностей віднесено й людський ресурс. О. Сомик надає також цікавого тлумачення феномену «ціннісних орієнтацій», як «..вектору та його складових працюючого механізму людської активності», як «...елемент світогляду особистості або групи людей, що визначає ті або інші переваги, необхідність та прагнення щодо виокремлених людських цінностей» (Сомик, 2019).

На основі аналізу теорії цінностей, ектраполюючи їі до економічної проблематики та вбачаючи в цінностях економічний контент, О. Сомік надає таку їх класифікацію (Сомик, 2019):

1. «Цінності соціально-економічного напрямку (відчуття свободи у виборі місця роботи; кваліфіковане та якісне виконання своєї роботи; стабільний прибуток; дружні стосунки в робочому колективі; престижність місця роботи та посади).

2. Цінності життєво-побутового напрямку (любов та сімейне щастя, спілкування з друзями, мати вільний час для свого хобі, читання книг та відвідування культурних заходів).

3. Цінності предметно-матеріального напрямку (добробут близьких, матеріальна забезпеченість, власний автомобіль та житло, жити краще ніж інші, отримання соціальних грошових допомог)» (Сомик, 2019).

Саме до формування першої групи цінностей цілком слушним $\epsilon$ застосування акмеологічних технологій. Оскільки вони $\epsilon$ інноваціями освітнього процесу професійної підготовки майбутніх фахівців на ґрунті принципу людиноцентризму, студентоцентризму, спонукання до саморозвитку, до найвищих результатів фахового росту під час навчання, набуття фахових компетентностей, формування траєкторії кар'єрного зростання в майбутньому.

Доцільно згадати суттєвий зміст педагогічної акмеології. За поясненнями О. Дубасенюк, остання визначається професійним аспектом, тобто професіоналізмом педагога, та «...своєрідністю поєднання об'єкта, умов, способів і технологій діяльності, результатів наукових досліджень, що акумулюються у праці педагога» (Дубасенюк та Сидорчук, 2012, с. 405). Педагогічна акмеологія саме й відрізняється своєю спрямованістю на досягнення педагогом, учителем, а під час навчання і студентом, найвищих 
досягнень професіоналізму, що підтверджується результативністю діяльності. О. Дубасенюк указує на гуманістичну зорієнтованість акмеології «... на розвиток особистості засобами окремих навчальних предметів»; «вибір педагогом способів своєї діяльності з урахуванням мотивів, ціннісних орієнтацій, цілей учнів»; а також на подальшу стратегію розвитку, зокрема в «...підготовці учнів до наступних етапів педагогічного маршруту» (Дубасенюк та Сидорчук, 2012, с. 405). Отже науковиця задекларувала саме індивідуальний, гуманістичний, ціннісно-орієнтаційний фокус акмеології в ії педагогічному векторі.

Поради, про які каже О. Дубасенюк, є слушними не лише в контексті педагогічної акмеології, а відповідно до професійної підготовки майбутніх фахівців у цілому. Зокрема, якщо йдеться про спеціально створену акмеологічну атмосферу навчання, то вона актуальна для підготовки майбутніх фахівців у цілому, оскільки відповідає концепції людиноцентичності та студоцентричності. Акмеологічне середовище, пояснює О. Дубасенюк, - «..це середовище прагнення до успіху, до творчості, до високих результатів діяльності, до досягнень кожного, коли престижно якісно працювати, викладати, навчатися, вести науковий пошук, дотримуючись морально-правових норм взаємодії» (Дубасенюк та Сидорчук, 2012, с. 404). Отже, таке середовище можна визначити як вільне, комплементарне до кожного, таке, що умотивовує кожного на творчість, прояв інтелектуальної активності, кращих своїх якостей.

Висновки. Проблема формування економічної компетентності майбутніх фахівців у контексті підвищення якості освіти зумовлена тим, що економічна проблематика пронизує всі сфери життєтворчості людини, детермінує їі економічну поведінку як у побуті, так і у професійній діяльності. Відповідно до сучасних актуальних поглядів на якість освіти, з точки зору відповідності не лише потребам суспільства, а й потребам особистості, економічна компетентність науковцями розглядається в структурі професійної компетентності фахівця. Нами встановлено, що вона охоплює економічну сферу майбутнього фахівця в особистісно-потребовому, гуманістичному, професійно-діяльнісному та ціннісно-орієнтаційному контекстах. Саме це стає чинником підвищення якості освіти, відповідній до сучасних ринкових умов. А механізмом стимулювання ії розвитку стають акмеологічні технології, які відповідають усім актуальним аспектам сучасної економічної проблематики. Отже, акмеологічні технології мають певний економічний потенціал у підвищенні якості професійної освіти.

Економічний потенціал акмеологічних технологій визначаємо як ефективний механізм педагогічної дії щодо створення атмосфери освітнього процесу, застосування відповідних умов, які забезпечують входження (прямо або опосередковано, реально та віртуально) особистості майбутнього фахівця до економічного сегменту суспільства в 
процесі професійної підготовки на основі формування зацікавленості, інтелектуальної допитливості, адаптаційної здатності, спроможності до ефективного застосування власного людського ресурсу.

\section{ЛІТЕРАТУРА}

Академія педагогічних наук україни. (2009). Біла книга національної освіти України. В. Г. Кремень (ред.). Київ. Режим доступу: http://www.ukraine3000.org.ua/img/forall/APN.pdf (Academy of Pedagogical Sciences of Ukraine. (2009). White Paper on National Education of Ukraine. V. H. Kremen (Ed.). Kyiv. Retrieved from: http://www.ukraine3000.org.ua/img/forall/APN.pdf).

Антонова, О. Є. (2016). Концептуальні теоретичні положення та підходи до вивчення природи обдарованості. Методика розвитку педагогічної обдарованості студентів. У О. А. Дубасенюк (ред.), Акмедосягнення науковців Житомирської науково-педагогічної школи, (сс. 71-102). Житомир: Вид-во ЖдУ ім. І. Франка. Режим доступу: http://eprints.zu.edu.ua/22730/1/Антонова\%200.pdf (Antonova, 0 . Ye. (2016). Conceptual theoretical positions and approaches to the study of the nature of giftedness. M ethods of development of pedagogical talent of students. In O. A. Dubaseniuk (Ed.), Acme-achievement of scientists of Zhytomyr scientificpedagogical school, pp. 71-102. Zhytomyr: Publishing house of ZhSU named after I. Franko. Retrieved from: http://eprints.zu.edu.ua/22730/1/Antonova\%200.pdf).

Белова, Л. (2018). Стан і проблеми здійснення управління якістю освіти та освітньої діяльності в Україні: Екпертне оцінювання (Belova, L. (2018). State and problems of implementing quality of education and educational activity management in Ukraine: Expert Evaluation). Theory and Practice of Public Administration, 2 (61), 1-10. Retrieved from: http://kbuapa.kharkov.ua/e-book/tpdu/2018-2/doc/1/1_1.pdf

Дубасенюк, О. А., \& Сидорчук, Н. Г. (2012). Дослідження проблем педагогічної акмеології у діяльності Житомирської науково-педагогічної школи. У В. Кремень, \& Т. Левовицький (ред.), Становлення і розвиток науково-педагогічних шкіл: Проблеми, досвід, перспективи: Збірник наукових праць, (сс. 404-413). Режим доступу: http://eprints.zu.edu.ua/12857/1/31.pdf (Dubaseniuk, O. A., \& Sydorchuk, N. H. (2012). Research of problems of pedagogical acmeology in activity of Zhytomyr scientific-pedagogical school. In V. Kremen, \& T. Levovytsky (Eds.), Formation and development of scientific-pedagogical schools: Problems, experience, prospects: Collection of scientific works, (pp. 404-413). Retrieved from: http://eprints.zu.edu.ua/12857/1/31.pdf).

Кінах, Н. В. (2017). Структура економічної компетентності педагога нової української школи (Kinakh, N. V. (2017). The structure of economic competence of a teacher of a new Ukrainian school). Science Review: Proceedings of the II International Scientific and Practical Conference «Topical issues of science and education» (December 18, 2017, Warsaw, Poland), 4(7), pp. 52-54. Retrieved from: https:// cutt.ly/conference.

Лодатко, Є. (2018). Формування економічної компетентності майбутнього вчителя у контексті викликів нової української школи. Гуманізація навчально-виховного процесу, 1 (87), 216-224. Режим доступу: http://journals.uran.ua/index.php/20771827/article/view/140445 (Lodatko, Ye. (2018). Formation of economic competence of the future teacher in the context of challenges of the new Ukrainian school. Humanization of the educational process, 1 (87), 216-224. Retrieved from: http://journals.uran.ua/index.php/2077-1827/article/view/140445). 
Любчук, О. К. (2018). До проблеми становлення економічної компетентності у студентів спеціальності «соціальна робота» у процесі професійної підготовки (Lubchuk, O. K. (2018). To the problem of economic competence in students of specialty "social work" in the process of professional training). Reporter of the Priazovskyi State Technical University. Section: Socially-humanitarian sciences and public administration, 1 158-163. Retrieved from: http://eir.pstu.edu/bitstream/handle/ 123456789/19695/c.\%20158163.pdf? sequence=1.

Москов, В. А. (2017). Модель формування економічної культури майбутніх кваліфікованих робітників будівельного профілю (Moskov, V. A. (2017). Model of economic culture formation of future qualified workers of building profile). International Scientific and Practical Conference "World Science", 4 (20), pp. 4549. Retrieved from: http://archive.ws-conference.com/category/ws2017-april/.

Сомик, О. (2019). Класифікація цінностей у контексті детермінант економічної активності (Somyk, 0. (2019). Classification of values in the context of determinants of economic activity). Evropský časopis ekonomiky a managementu, 5 (4), 104-109. Retrieved from: https://eujem.cz/wpcontent/uploads/2019/eujem_2019 5_4/eujem_2019_5_4.pdf\#page=104.

Хлєбнікова, Т. М. (2011). Кваліметричний підхід до вивчення якості вищої освіти. Теорія та методика управління освітою, 5. Київ: Ун-т менеджменту освіти НАПН України. Режим доступу: http://tme.umo.edu.ua/docs/5/11hleqhe.pdf (Khliebnikova, T. M. (2011). Qualimetric approach to the study of the quality of higher education. Theory and Methods of Educational Management, 5. Kyiv: University of Management of Education of NAPS of Ukraine. Retrieved from: http://tme.umo.edu.ua/docs/5/11hleqhe.pdf).

Яворська, Г. Х., Гладкова, В. М., \& Горчакова, О. А. (2012). Основи акмеології для менеджерів освіти. Київ: Освіта України (Yavorska, H. Kh., Hladkova, V. М., \& Horchakova, O. A. (2012). Fundamentals of Acmeology for Education M anagers. Kyiv: Education of Ukraine).

\section{PEЗЮME}

Очеретная Ольга. Экономический потенциал акмеологических технологий в повышении качества профессионального образования.

В статье актуализирована проблема качества образования в контексте современной компетентностной парадигмы, реформирования образовательного пространства и влияния на них экономического фрактора. Обращено внимание на человекоцентрический аспект качества образования, в рамках которого учтен как общественно-потребностный контекст, так и индивидуально-потребностный. Акцентирована значимость экономической компетентности будущего специалиста, которая корреспондируется по функции с интегральной компетентностью и может быть применена как в рамках профессиональной деятельности, так и в социокультурном пространстве в целом. В этом ракурсе рассмотрен потенциал акмеологических технологий, которые являются удобным, современным и действенным педагогическим средством развития личности и ее профессионального роста, в частности, влияя и на экономическую компетентность личности.

Ключевые слова: качество образования, экономическая компетентность будущего специалиста, акмеологические технологии, экономический потенциал акмеологических технологий. 


\section{SUMMARY}

Odheretna Olha. Economic potential of acmeological technologies in improving quality of vocational education.

At the turn of the XX and XXI centuries the issue of the quality of education, its measurement is the subject of interest of the scientists, educational management and public institutions. The quality of education and its evaluation depends on the needs of the state, its development strategy. Recent reforms and definitions of the way of development of the state according to the democratic principle of European education strategies actualize not only the issue of social need, but also the personal needs of each future specialist, giving him the opportunity to freely choose the trajectory of professional formation, self-realization and self-development.

Taking into account the conditionality of almost all aspects of state development, including the quality of education, economic pedagogy pays special attention to this issue. This is manifested through a scientific reflection of such a quality as economic competence. It is substantiated that economic issues permeate all spheres of human life, determine its economic behavior in various spheres. In the context of the quality of education, it addresses both the needs of society and the needs of the individual. It is specified that the economic sphere of the future specialist is manifested in such aspects that become factors of the quality of education in accordance with modern market conditions: personality-need, humanistic, professional-activity, value-orientation.

It is shown that the mechanism of stimulating development of the economic sphere of the person can be acmeological technologies that meet all relevant aspects of the current economic problems. The economic potential of acmeological technologies has been determined - it is an effective mechanism of pedagogical influence on the creation of an atmosphere of the educational process, application of appropriate conditions that ensure the entry (directly or indirectly, real and virtual) of the future specialist into the economic segment of society in the process of professional training on the basis of interest, adaptive capacity, readiness of the individual to use effectively their own human resources.

Key words quality of education, economic competence of the future specialist, acmeological technologies, economic potential of acmeological technologies.

Удк 378. 14: 796. 011.3

Антоніна Розсоха

ДВНЗ «Переяслав-Хмельницький ДПУ імені Григорія Сковороди» ORCID ID 0000-0001-8877-4243

Михайло Кравець

ДВНЗ «Переяслав-Хмельницький ДПУ імені Григорія Сковороди»

ORCID ID 0000-0001-7677-1416

DOI 10.24139/2312-5993/2019.07/276-285

\section{ПЕДАГОГІЧНІ УМОВИ ПІДГОТОВКИ МАЙБУТНІХ УЧИТЕЛІВ ФІЗИЧНОЇ КУЛЬТУРИ ДО КРАЄЗНАВЧОЇ ДІЯЛЬНОСТІ}

У статті здійснено аналіз педагогічних умов підготовки майбутніх учителів фізичної культури до краєзнавчої діяльності. Обгрунтовано актуальність дослідження проблеми ефективної організачії підготовки майбутніх учителів 